\title{
Reconstruction of Criminal Sanctions On Actors Of Online Prostitution Based On Justice Value
}

\author{
Ratih Mega Puspasari ${ }^{1}$
}

\begin{abstract}
Cybercrime is one shape is one of the dark side of technological progress. One form of crime in the area of cybercrime that is online prostitution. In the positive law in Indonesia only prohibits those helping and providing illegal sexual services, meaning that the prohibition only given to pimps, brokers, and prostitutes while users of commercial sex itself is absolutely no chapters that govern them. The purpose of this study to find out the settings in Indonesian positive law against online prostitution service users and to determine judicial review against online prostitution service users based on the positive law in Indonesia. Research conducted in this thesis is a normative legal research. This study used the approach of legislation and the comparative approach. Legal materials used are the primary legal materials, secondary and tertiary. Further legal material collection techniques in this research is literature study, then do a normative analysis of qualitative and describe it in the form of research. The survey results revealed that the arrangement of positive law in Indonesia to service users are not yet effective in the trap and tackling online prostitution, because it did not regulate the service users in an online prostitution a criminal offense. Overview jurisdiction over the online prostitution by No. 11 of 2008 on Information and Electronic Transactions and Act No. 44 Of 2008 on Pornography does not mention the provisions on service users online prostitution in particular, so that the two laws even this can't ensnare the service user online prostitution.
\end{abstract}

Keywords: Reconstruction; Criminal Sanctions; Online Prostitution; Justice.

\section{Introduction}

These technological advances in addition to a positive impact, in the sense that can be utilized for the benefit of mankind also bring negative impacts on human development and civilization. The negative impact in question is related to the world of crime. JESahetapy has stated in writing, that the crime is closely related and even become part of the results of the culture itself. This means that the higher the level the more modern culture and a nation, the more modern it is also a crime in the form, nature and ways of their implementation ${ }^{2}$.

Broadly speaking, crimes related to information technology can be divided into two major parts. First, crime aimed at undermining or attack the system or computer network. And secondly, crimes using computers or the Internet as a tool in crime launched ${ }^{3}$.

\footnotetext{
${ }^{1}$ PPAT and Student Doctor of Law, Sultan Agung Islamic University in Semarang, email:ratihmegapuspa@gmail.com.

${ }^{2}$ Endang Sedyaningsih, Women Keramat Stumps Jakarta: Pustaka Sinar Harapan, 1999, p. 88

${ }^{3} \mathrm{http}$ : //www.hukumonline.com/klinik/detail/lt52f04db5110f4/ancaman-sanctions-for-the-spot-establishprostitution, accessed on 19 April 2019
} 
Cyber crime prostitution in Indonesia was first revealed in May 2003 where at that time Reskrimsus cybercrime unit of the Jakarta Police managed to arrest cyber pimp. The culprit is a husband and wife, Ramdoni as Rino and Sari Yanti as Bela. This cyber prostitution is a new mode that is by offering women through a web address. The owner of this web displaying photographs of women with minimal clothing that is ready to serve the customer ${ }^{4}$. Enthusiasts just simply call the phone number displayed pimps posted on the web, then pimping this that leads back to the bedroom hotel booking or apartment accordance with customer wishes ${ }^{5}$.

People usually know prostitution is carried out in an area or place, whether it's on a side street, a side rail, localization or other places with the way actors hawking himself and wait for customers to come his services users. With the development of science and technology today as well as the impact of globalization in ways that do in the deal is already diverse, no longer to meet each other in the usual places selling themselves. Using the internet media is one of them. This media is more secure than a direct selling in roadside or localization. With the existence of this medium one can be more flexible in trade, should not meet each other directly between an offender prostitution by people who want to use his services ${ }^{6}$.

Ethics violations including cyberporn and prostitution by electronic means or internet. In this case cyberporn is more closely related to the new media or online using the internet network to use. While porn or pornography, he said (from the Greek pornographia literally writing about or pictures of prostitutes, sometimes abbreviated to the depiction of the human body or human sexual behavior openly (explicit) with the purpose of desire (libido) ${ }^{7}$.

\section{Research Methods}

This research is a normative legal research, the research done by reviewing the legislation in force or applied to a specific legal problem. Normative research is often called a doctrinal study, the research object of study is to document the legislation and and literature study ${ }^{8}$.

\footnotetext{
${ }^{4}$ E.Y Kanter, Asas-asas Hukum Pidana di Indonesia dan Penerapannya Jakarta: Storia Grafika 2012 ${ }^{5}$ Farhana, Aspek Hukum Perdagangan Orang di Indonesia, Jakarta: Sinar Grafika, 2010, p. 124

${ }^{6}$ C.S.T. Kansil, Pengantar Ilmu Hukum dan Tata Hukum Indonesia, p. 165.

7 http://ekosupriyanto50.blogspot.com/2013/04/pengertian-cyberporn.html accessed on February 14, 2019.

${ }^{8}$ Soejono dan H. Abdurahman, 2003, Metode Penelitian Hukum, Rineka Cipta, Jakarta, p. 56
} 


\section{Discussion}

\subsection{Online prostitution}

Online Prostitution is derived from two words, each of which can stand alone namely prostitution and online. Prostitution is a term that is equal to prostitution. Prostitution according Soerjono Soekanto can be defined as a work that is surrendered to the public to perform sexual acts with a reward ${ }^{9}$,

The last word of the term online prostitution describe the place where the activity is performed. Online is a term that people use to express something related to internet or cyberspace. Online prostitution is an activity offering services sexual services through cyberspace or Internet service includes direct communication (email, chat), discussions (Usenet, News, E-mail, mailing lists), resource information distributed (World Wide Web, Gopher ), remote login and file traffic (Telnet, FTP), and various other services ${ }^{10}$.

In the discussion about online prostitution is to discuss the practice of prostitution or prostitution by using the Internet or online media as a means of transactions for commercial sex workers and those who want to use his services.

If we want to deepen the understanding of the meaning of online prostitution is prostitution transaction that uses the internet as a means of liaison between commercial sex workers with who wants to use his services. So the Internet only as a means of supporting or connecting only.

\subsection{Media used}

In prostitution there are several kinds of internet media used by a prostitute to perform the work ${ }^{11}$ : 1) Website; 2) Forum; 3) Social Networking; 4) Application; suppose a program to chat (Chat) telephone voice (Voice Call) or telephone images (Video Call). Being so these programs Massanger example is Yahoo, Camfrog, mIRC, Skype.

\subsection{The culprit in the practice of the crime of online prostitution}

Here are some of the perpetrators of criminal acts in the practice of online prostitution $^{12}$ : 1) A pimp; "Owner" of commercial sex workers (CSWs); 2)

\footnotetext{
${ }^{9}$ Romli Atmasasmita, 2010, Teori dan Kapita Selekta Kriminologi, Refika Aditama, Bandung, p. 329

10 http://www.negarahukum.com/hukum/dilema-menjerat-prostitusi- online.html. Accessed on 23 November 2018

${ }^{11}$ Ibid.

${ }^{12}$ Tahnh-Dam Truong, Pariwisata dan Pelacuran di Asia Tenggara, Terjemahan: Moh. Arif, Jakarta: LP3ES, 1992, p. 68
} 
Commercial sex workers (CSWs); 3) Other parties; server owner, the owner of the website or forum; 4) The service users PSK.

\subsection{Positive law setting User Services In Indonesia Against Online Prostitution}

So far the government only regulates prostitution problem asserted in criminal law prohibits only those who help and provide sexual services is illegal as written in the Book of Penal (Penal Code) Article 296, Article 297 of the Criminal Code, Article 506 of the Criminal Code also prohibits trafficking in women and children under age. Such articles of the Criminal Code prohibits only those who help and provide sexual services illegal, meaning that the prohibition only given to pimps. Nonetheless criminal law remains the basis of the rules in the sex industry in Indonesia ${ }^{13}$.

Because of the prohibition of sexual services, especially to the practice - the practice of prostitution does not exist in state law, then the rules in the sex industry have tended to be based on the rules - the rules issued by the local government, both at the provincial, district and sub-district, taking into account the reaction, action and pressure of various community organizations that are supporting and opposing prostitution.

Combating prostitution of legal substance issues set out in the Code of Penal Legislation and Regulations specifically created to address the regulation of prostitution does not look the parties customer or user of commercial sex services that can be charged with criminal sanctions. Act No. 11 of 2008 on Information and Electronic Transactions and Act No. 44 of 2008 on Pornography only prohibit a service provider, the person who funded and commercial sex workers as an object in the crime of online prostitution. So that those who use the services of commercial sex can freely without fear of being caught in the criminal law sanctions ${ }^{14}$.

Arrangements regarding the prohibition against online prostitution is specifically provided for in Article 27 paragraph (1) of Act No. 11 Of 2008 on Information and Electronic Transactions which formulated the prohibited acts are: "Every person intentionally and without right to distribute and / or transmits and / or make the inaccessibility of Electronic Information and / or Electronic Documents which have a charge of violating decency ${ }^{15 "}$

Viewed from this article explanation only regulate its service providers only, does not regulate the online prostitution service users, so that this law can

\footnotetext{
${ }^{13}$ Mr. Tresna, 1959, Asas-Asas Hukum Pidana, PT. Tiara, Jakarta, p. 27.

${ }^{14}$ Tanjung, Armaidi, dan Delfita, Elfi, Mengapa Zina dilarang, Solo: CV Pustaka Mantiq, 2001, p. 218

${ }^{15}$ Terence H, Hull, Endang Sulistianingsih, Gavin W.J, Pelacuran di Indonesia Jakarta: Pustaka Sinar Harapan, 1997, p. 230
} 
not ensnare the service user's online prostitution. It is unfortunate in Act No. 11 of 2008 on Information and Electronic Transaction does not regulate the whole subject in online prostitution itself 16 .

Regarding online prostitution, Act No. 44 of 2008 on Pornography does not directly mention the word online prostitution, but in law it is a more complete and detailed to explain the practice of online prostitution in comparison with Act No. 11 Of 2008 on Information and Electronic Transactions (UU ITE) ${ }^{17}$.

Prostitution stipulated in this law be clarified in article 4, paragraph (2) d of Act No. 44 Of 2008 on Pornography contents of the article on the prohibition and restriction. Content of Article 4 (2) d namely: "Everyone is prohibited from providing services which offer or advertise pornography, either directly or indirectly, of sexual services."

Looking back at article 1, paragraph (2) and connect it with article 4, paragraph (2) d, then the practice of online prostitution be criminalized. Because it has as criminal elements in the aforementioned article. As an element of obscenity and sexual exploitation in article 1, paragraph (2) and elements that offer sexual services. In addition internet media is set to the media of intermediary activities such as prostitution leads to pornography online. Regarding the parties involved in the practice of online prostitution, pimps, owners of websites or forums, commercial sex workers and the owner of the server. Pornography law is more straightforward in mentioning these parties. In chapter 7 laws pornography contents are: "Every person is prohibited from funding or facilitating acts as referred to in Article 4."

In this article is that the funding or facilitating the resulting action set out in article 4 of Act No. 44 of 2008 on Pornography which consists of two paragraphs. As such, the discussion here is about the online prostitution, then charged to the proponent or facilitating online prostitution is article 4 paragraph (2) d due to meet the elements of the party who facilitates online prostitution that offer sexual services $^{18}$,

The website owner can be convicted in accordance with the provisions of article 4 and article 7 of Act No. 44 of 2008 on Pornography as offering commercial sex workers on its website as well as a pimp, by facilitating commercial sex workers for users of commercial sex services.

Conditions sanctions in pornography laws, also regulated specifically refers to the parties involved. As in article 30 of Act No. 44 Of 2008 on Pornography, whose contents are: "Every person providing services pornography as referred to in

\footnotetext{
16 Tikometer, "Pertumbuhan domain.id" http://www.tikometer.or.id/berita-37- Pertumbuhan-domainid.html accessed on 25 Desember 2010..

${ }^{17}$ Tongat, Pidana Seumur Hidup dalam Sistem Hukum Pidana di Indonesia, Malang: UMM Press, 2004, p. 72

${ }^{18}$ Act No. 11 of 2008 on Information and Electronic Transactions, Surabaya: Top Kesindo 2008.
} 
Article 4 paragraph (2) shall be punished with imprisonment of 6 (six) months and not later than 6 (six) years and / or fined at least Rp250,000,000.00 (two hundred and fifty million rupiah) and at most Rp3.000.000.000,00 (three billion rupiah). ${ }^{19 "}$

Other criminal provisions set out in Article 35 of Act No. 44 Of 2008 on Pornography namely: "Every person who makes other people as objects or models that contain pornographic content as referred to in Article 9 shall be punished with imprisonment of a minimum of 1 (one) year and a maximum of twelve (12) years and / or fined at least 500,000,000.00 (five hundred million rupiah) and at most Rp6.000.000.000,00 (six billion).20"

\subsection{Reconstruction Of Criminal Sanctions On Actors Of Online Prostitution Based On Justice Value}

In terms of providing clarity regarding the reconstruction of criminal sanctions on actors of online prostitution based on justice value will be explained as follows:

a. The certainty of legislation regarding criminal prosecution and sanctions, not only online prostitutes in this case prostitution but also the owners, marketers and users;

b. The existence of criminal sanctions are clear and definite number is and also the provision of high fines to be able to provide a deterrent effect against perpetrators of those about online prostitution;

c. Provision of socialization for parties online prostitution either through religious approach, psychological, medical and so on, that the act is a crime that can be prosecuted by law, so hopefully they do not do it;

d. Formation of Regional Regulation (Perda) of the Public Order in this case the prevention of online prostitution in each area, because the type of crime through online prostitution each region is different.

\section{Conclusion}

Until now there has been no appropriate and effective formula to solve the problem of prostitution fully and firmly. However, when compared with the positive law in Indonesia in general, of course Establishment Bylaw on Public Order is the most appropriate solution to provide criminal sanctions for offenders and users prostitution services online. Because this regulation only regulates specifically (lex specialist) to certain areas that can not be applied in other areas.

\footnotetext{
${ }^{19}$ Act No. 44 of 2008 on Pornography, Surabaya: Top Kesindo 2008.

${ }^{20}$ Sawitri Nandari, Ni Putu, Penanggulangan Pelacuran Di tinjau Dari Perspektif Hukum dan Gender, T.tp.
} 


\section{Bibliography}

[1] E.Y Kanter, Asas-asas Hukum Pidana di Indonesia dan Penerapannya Jakarta: Storia Grafika 2012.

[2] Endang Sedyaningsih, Perempuan Keramat Tunggak Jakarta: Pustaka Sinar Harapan, 1999.

[3] Farhana, Aspek Hukum Perdagangan Orang di Indonesia, Jakarta: Sinar Grafika, 2010.

[4] Mr. Tresna, 1959, Asas-Asas Hukum Pidana, PT. Tiara, Jakarta.

[5] Romli Atmasasmita, 2010, Teori dan Kapita Selekta Kriminologi, Refika Aditama, Bandung

[6] Sawitri Nandari, Ni Putu, Penanggulangan Pelacuran Di tinjau Dari Perspektif Hukum dan Gender, T.tp.

[7] Soejono dan H. Abdurahman, 2003, Metode Penelitian Hukum, Rineka Cipta, Jakarta.

[8] Tahnh-Dam Truong, Pariwisata dan Pelacuran di Asia Tenggara, Terjemahan: Moh. Arif, Jakarta: LP3ES, 1992.

[9] Tanjung, Armaidi, dan Delfita, Elfi, Mengapa Zina dilarang, Solo: CV Pustaka Mantiq, 2001.

[10] Terence H, Hull, Endang Sulistianingsih, Gavin W.J, Pelacuran di Indonesia Jakarta: Pustaka Sinar Harapan, 1997.

[11] Tongat, Pidana Seumur Hidup dalam Sistem Hukum Pidana di Indonesia, Malang: UMM Press, 2004

[12] Tikometer,"Pertumbuhan domain.id" http://www.tikometer.or.id/berita-37Pertumbuhan-domain-id.html accessed on 25 Desember 2010.

[13] http://ekosupriyanto50.blogspot.com/2013/04/pengertian-cyberporn.html accessed on February 14, 2019.

[14] http://www.hukumonline.com/klinik/detail/lt52f04db5110f4/ancamansanctions-for-the-establish-prostitution areas, accessed on 19 April 2019

[15] http://www.negarahukum.com/hukum/dilema-menjerat-prostitusionline.html. Accessed on 23 November 2018

[16] The Code of Penal

[17] Act No. 11 of 2008 on Information and Electronic Transactions (UU ITE).

[18] Act No. 44 Of 2008 on Pornography

[19] Act No. 21 of 2007 on Combating Trafficking in Persons. 